\title{
Reproductive ecology of the temperate reef fish Cheilodactylus spectabilis (Pisces: Cheilodactylidae)
}

\author{
Mark I. McCormick* \\ Leigh Marine Laboratory, University of Auckland, Private Bag, Auckland, New Zealand
}

\begin{abstract}
Reproductive cycle and behaviour of the large temperate reef-fish Cheilodactylus spectabilis was studied off the northeast coast of New Zealand to determine how reproductive events influenced the distribution patterns of males and females on the reef. $C$. spectabilis appears to be a summer-autumn serial spawner, with ripe males having very small testes relative to their body size. Censuses over a mapped area of reef during and after the breeding season revealed no large-scale shifts in distribution pattern. However, on a within-day basis ripe females visited large males on the reef edge, peaking in density at dusk. Behavioural observations found these males to be highly territorial towards similar sized conspecifics, with particular sites being defended by the same fish over a number of years. One spawning event was observed in a cave at dusk. The number of ripe females visiting a male's territory over the breeding period was related to the presence of conspicuous caves. C. spectabilis appears to exhibit a form of resource defence polygyny.
\end{abstract}

\section{INTRODUCTION}

Reproductive events can have a profound effect on the spatial and temporal distribution of a species in its environment. In many fishes breeding involves a change in the distribution patterns maintained throughout the non-breeding period of the year. The reproductive ecology of a species, its gonad maturation and inherent sexuality (whether hermaphroditic or gonochoristic) interact with other aspects of its ecology, such as foraging and maintenance behaviour, to determine the social organization of the species i.e. where an individual is in the reef environment and what it does.

A wide range of reproduction-associated movement and behaviour patterns are exhibited by demersal reef fish (reviewed by Thresher 1984). Many small sedentary fishes form territories which are maintained yearround or established solely for breeding, and spawn demersal eggs which are guarded until hatching. Examples of this mode can be found in a number of reef fish families such as the Pomacentridae, Siganidae, Balistidae, Tetraodontidae, Gobiidae and Blenniidae

\footnotetext{
- Present address: Department of Marine Biology, James Cook University, Townsville, Queensland 4811, Australia
}

(Johannes 1978). In contrast, other fishes undertake either solitary or group migrations to the outer edge of the reef to spawn in large aggregations. Such migrations have been documented in one or more species of scarid (Randall \& Randall 1963, Choat \& Robertson 1975), serranid (Fischer 1980), acanthurid (Robertson 1983), lutjanid (Johannes 1981), and labrid (Thresher 1984). Much of the information on the reproductive ecology of reef fish has consisted of single behavioural observations and anecdotal accounts of spawning events. Detailed documentation of reproductive ecology has concentrated on small, highly territorial reef fish, particularly of the family Pomacentridae (e.g. references in Thresher 1984). Few studies have examined the larger, more mobile reef fish species which are often fished commercially or recreationally (e.g. sparids, lutjanids, lethrinids, cheilodactylids). In such cases, a knowledge of the influence of life history events, such as reproduction, on the local distribution patterns can have important management implications.

The aim of this paper is to describe the reproductive ecology of the large demersal reef fish Cheilodactylus spectabilis (Hutton). The distribution patterns of male and female C. spectabilis over a wide range of temperate reef habitats were described by McCormick (1989). 
Males dominated the deeper parts of the reef, while females and juveniles occurred inshore. In this study, the link between the reproductive cycle, social organization and temporal changes in the local distribution pattern of the fish is examined. Four specific questions are posed: What is the nature of the reproductive cycle of C. spectabilis? What does this suggest about the nature of the spawning event? Are all elements of the reproductive population involved in spawning over a particular breeding season? What influence does reproduction have on the spatial distribution of the species?

\section{MATERIALS AND METHODS}

The species. Cheilodactylus spectabilis is widely distributed over the shallow reef habitats of northern New Zealand (McCormick \& Choat 1987). It is a large slowmoving fish growing to $550 \mathrm{~mm}$ standard length (SL), which makes it ideal for a variety of visual sampling techniques. The sexes can be distinguished externally down to ca $240 \mathrm{~mm}$ SL (McCormick 1989).

Study area. Cheilodactylus spectabilis were monitored at Tabletop Reef, located in the Cape Rodney to Okakari Point Marine Reserve on the northeastern coast of New Zealand $\left(174^{\circ} 47^{\prime} E_{i} 36^{\circ} 16^{\prime} S\right)$. A strip of reef, ca $350 \times 100 \mathrm{~m}$, extending offshore was mapped in detail. This was divided into similar sized shallow $(<9 \mathrm{~m})$, mid ( 9 to $17 \mathrm{~m})$. Deep $1(17$ to $23 \mathrm{~m}$ ) and Deep 2 $(<23 \mathrm{~m})$ study sites. Algal-covered reef extended from a shallow heavily dissected platform to a series of large, sheer-sided blocks interspersed with cobble and sand gutters. The dominant algae were the laminarian kelp Ecklonia radiata and the fucoid Carpophyllum maschalocarpum. The deepest study site $\left(7200 \mathrm{~m}^{2}\right)$ consisted of a mosaic of low-lying reeflets surrounded by sand.

Sampling. Cheilodactylus spectabilis were collected from a range of habitats similar to those present at the Tabletop monitoring site (0 to $20 \mathrm{~m}$ depth). Seasonal samples were collected at ca $3 \mathrm{mo}$ intervals from islands within the Hauraki Gulf (Little Barrier and Hen Islands) off the northeast coast of New Zealand, with the exception of the summer sample. This sample was collected from the adjacent Leigh coast and Takatu Point (see Fig. 1, McCormick \& Choat 1987; Fig. 2, Jones 1984). Collections began in May 1984 and ended in March 1985. Each consisted of between 21 and 47 individuals covering the available size range. A total of 138 fish were sampled.

The standard length of each fish was measured to the nearest $\mathrm{mm}$ and its total weight recorded. All gonads were dissected fresh and stored in Bouin's fixative for later transferal to $90 \%$ isopropanol. Gonads were wetweighed $( \pm 0.01 \mathrm{~g})$ and sectioned for histological examination. Sections of 5 to $10 \mu \mathrm{m}$ were cut and stained by the Mallory-Heidenhain 1-step method. Gametogenesis was divided into arbitrary stages. Five stages were defined for oogenesis following Tong \& Vooren (1972): oogonia, primary oocyte, vacuolation, vitellogenesis, mature eggs. Four stages were defined for spermatogenesis (Moe 1969): spermatogonia, spermocytes, spermatids, spermatozoa. The proportion of each gonad development stage was determined for each section using an ocular graticule.

Spatial distribution. During 1985, monthly swim searches were conducted over the 4 depth sites of Tabletop Reef. Censuses spanned January to December inclusive for the shallow, mid and Deep 1 sites. Censuses of the Deep 2 study site were initiated in April and ended in December. No November census was made at any of the sites. McCormick (1989) showed that a single census gave a representative sample of the abundance and size structure of the population at the shallow and mid sites for a given month. It is assumed that a representative sample of the sex distribution of the population was also obtained. During a census the position of each Cheilodactylus spectabilis seen, together with an estimate of its size (to the nearest centimetre) and sex (male, female or juvenile) was recorded (as detailed by McCormick \& Choat 1987, McCormick 1989). The presence of a distended abdomen in females was indicative of being part of the reproductive population and was also noted. Destructive sampling of such females during autumn validated this method.

During the peak of the breeding season (April and May), a large number of reproductively active fish were observed at the Deep 2 study site. Sampling effort was therefore concentrated at this site, with censuses conducted at 6 times of the day. Three censuses were swum at each of dawn, midday and dusk. Single censuses prior to dawn and dusk and at midnight were also conducted. Three replicate censuses were also swum at 3 times during the day outside the breeding season.

The area of each reeflet in the Deep 2 site was determined from detailed maps, and a measurement of maximum height enabled the calculation of the approximate volume of each reeflet. The presence of conspicuous cave and tunnel systems was also noted. Caves were defined as depressions in the side of the reef at least $0.5 \mathrm{~m}$ deep and $0.25 \mathrm{~m}$ height and width at the entrance. These physical factors were then related to the number of females recorded on each of the patch reefs during the reproductive season.

Behaviour. Observations totalling $24 \mathrm{~h}$ were made on individually recognizable fishes between March and June 1985 at the Deep 2 study site. Fishes were identified by size, variations in their banding patterns and scars. During censuses the position and identity of 
recognizable fish was noted. The depth of water did not allow long periods of observation on individual fish. To measure differences in the patterns of activity over time of day, in and outside the breeding season at the Deep 2 site, an instantaneous sample of the fish behaviours was taken during each census. Fish were placed into one of 3 behavioural categories when first seen: (1) Resting - stationary on the bottom; (2) Swimming actively moving, head not orientated toward substratum; (3) Foraging - head orientated down, moving slowly over substratum, including the capture and processing of food.

\section{RESULTS}

\section{Reproductive cycle}

For the major part of the year gonad tissue takes up less than $10 \%$ of the body cavity. During the breeding season, the ovaries of a mature female may swell to encompass over one-third of the body cavity. In a large female this can represent up to a 20 -fold increase in

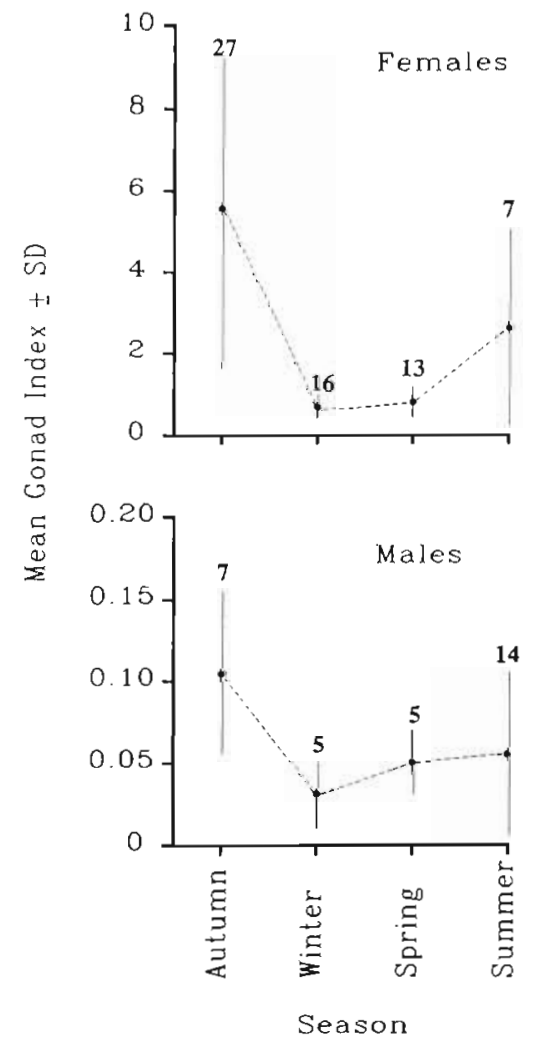

Fig. 1. Cheilodactylus spectabilis. Mean gonadosomatic index values for males and females over 4 seasons ( \pm 1 standard deviation). Values were calculated only for individuals above the minimum length at sexual maturity $(250 \mathrm{~mm}$ SL females, $300 \mathrm{~mm}$ SL males). Numbers of fish sampled also given

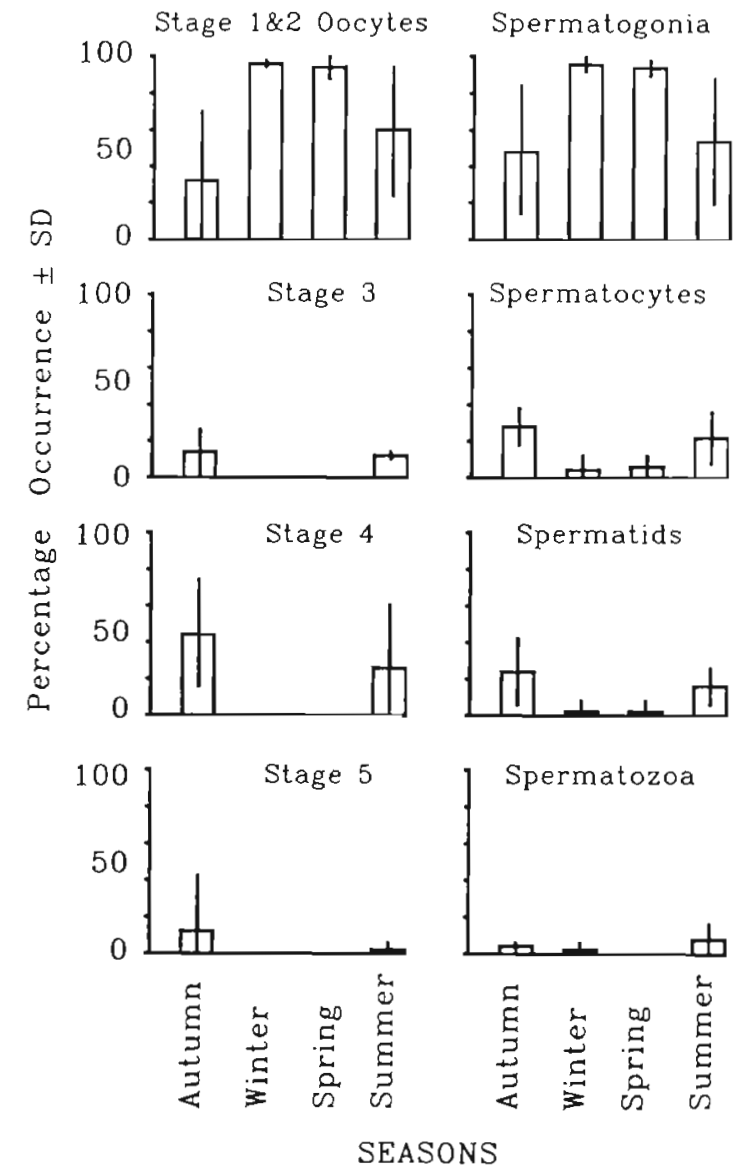

Fig. 2. Cheilodactylus spectabilis. Mean percentagefrequency distributions of gametocyte stages over 4 seasons ( \pm 1 standard deviation)

gonad weight (9 to $180 \mathrm{~g}$ for a $340 \mathrm{~mm}$ SL individual). At this time ovaries can be up to 2 orders of magnitude larger than testes for ripe individuals of the same size (e.g. $180 \mathrm{~g}$ compared to $3 \mathrm{~g}$ for $340 \mathrm{~mm}$ SL individuals).

A gonadosomatic index (gonad weight $\times 100 /$ body weight-gonad weight) was used to follow the changes in the annual cycle of gonad development. The autumn peak in the index for both males and females is indicative of the spawning season (Fig. 1). The high variation around the gonad index-means for the females is due to the large difference between gonad sizes in matureripe and immature (although ripening) individuals. This suggests that the whole population is not synchronized in its spawning. It is noteworthy that there is an order of magnitude difference between the mean index values for males and females $(0.11$ and 5.79 respectively).

Changes in the frequency of the gametogenic stages within the gonads indicates the seasonality of the spawning cycle (Fig. 2). Only oogonia and primary oocytes were present in the ovaries during winter and spring, while testes were dominated by spermatogonia. By summer, 
vacuolated oocytes had developed, many reaching the previtellogenic stage. At the same time, spermatocytes and spermatids occurred in mature males. Gonads were developed to breeding condition in autumn with the predominance of vitellognic oocytes in females and spermatocytes in males. This gametogenic cycle, although based on only 4 sampling periods, suggests that Cheilodactylus spectabilis is a serial spawner which has an extensive spawning period from summer through to autumn. Development of the sex cells is asynchronous and gonads contain gametes of all stages of development throughout the reproductive period. This is considered typical of fish that spawn more than once in a season (Yamamoto \& Yoshioka 1964).

Histology indicated that sexual maturity of females occurs at ca $250 \mathrm{~mm}$ SL. The small sample of 8 males collected in the autumn sample suggests that males mature at the larger size of $300 \mathrm{~mm} \mathrm{SL}$.

\section{Spatial patterns}

The distribution pattern of male and female Cheilodactylus spectabilis over Tabletop Reef during the breeding season different little from the average distribution over the whole year (Fig. 3). Ripe females occurred at all depths, while unripe females only occurred in the shallower sites. During the reproductive period the number of ripe females present at the deepest site was comparatively high and the numbers of females at shallower sites comparatively low (Fig. 3). This suggests some systematic movement. Males show little sign of such a pattern.

An examination of the distribution patterns over the whole $24 \mathrm{~h}$ period at the Deep 2 study site suggests a systematic diel migration of both male and female Cheilodactylus spectabilis (Fig. 4), Males are present at the patch reef system throughout the $24 \mathrm{~h}$ period and show a significant increase from predawn to dusk. Females were not present during the night or at dawn, but migrated into the area throughout the morning and afternoon, also peaking in density at dusk. The smallest female counted in all of the censuses during the breeding season was $270 \mathrm{~mm}$ SL. All had highly distended abdomens characteristic of their ripe breeding state. The smallest male at the deep site was $320 \mathrm{~mm}$ SL. Dawn. dusk and midday censuses well after the breeding season (August) did not exhibit a similar influx of females onto the deep reef throughout the day (Fig. 4). Moreover, the smaller males, which were virtually absent from the May censuses, were present in August. Poor or no relationships were found between the number of female $C$. spectabilis seen on reeflets with males and the area or volume of the reeflets $\left(r^{2}=0.09\right.$, $n=29, \mathrm{NS} ; r^{2}=0.17, p<0.05, n=29$ respectively).

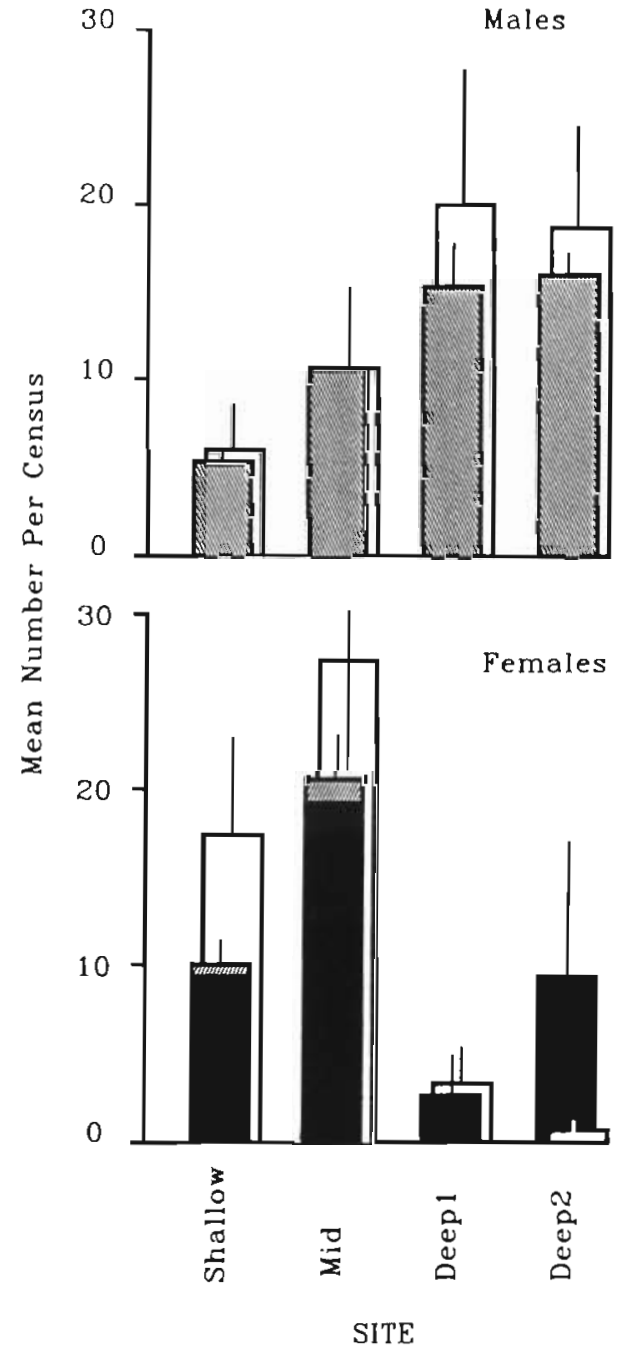

Fig. 3. Cheilodactylus spectabilis. Upper: Comparison of frequency distributions for males over the 4 depth sites of Tabletop Reef over the whole of 1985 (open bars; $n=10$ censuses), with the distribution during 2 mo of the reproductive season (shaded bars). Lower: Frequency distributions for females over the whole year (open bars) and for ripe (black bars) and unripe (shaded bars) females during the reproductive season. Error bars represent 1 standard deviation. Individuals $<240 \mathrm{~mm}$ SL are not included as these cannot be consistently sexed

\section{Behaviour}

The individual identification of males on the Deep 2 site patch reefs from April to December indicated that they were territorial to conspecifics of similar size. Large males were associated with reeflets large enough to have either cave, gulley or ledge systems. Typically, a single male larger than $450 \mathrm{~mm}$ SL resided on a reeflet. No resident was seen to be displaced in a territorial dispute. Moreover, the same recognizable individuals were resident in at least 3 of the reeflet- 


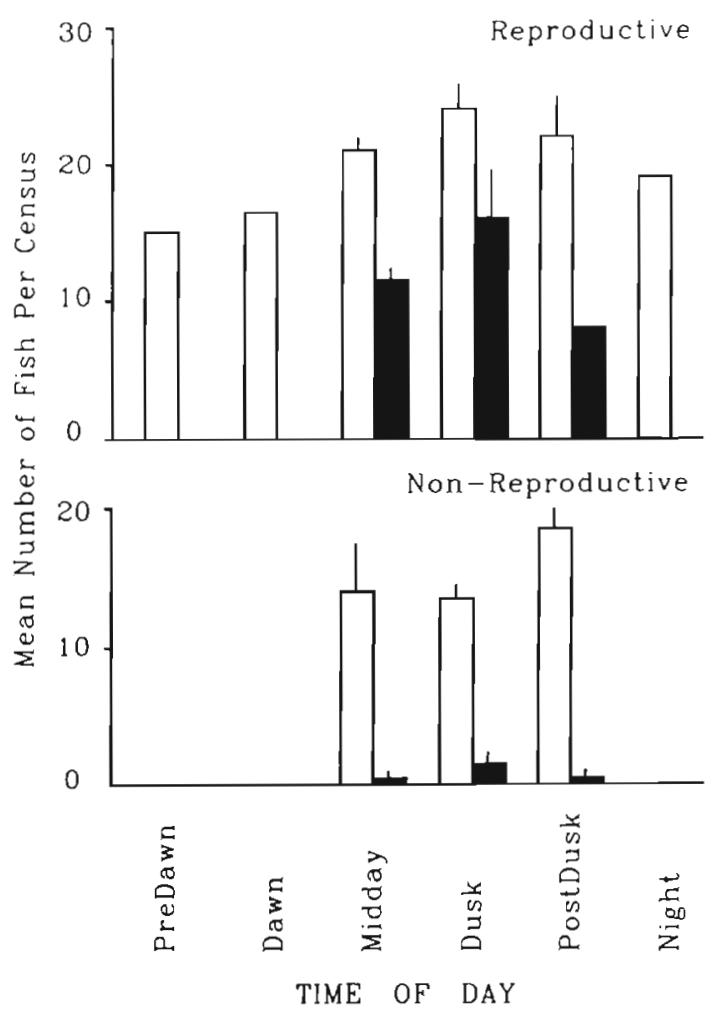

Fig. 4. Cheilodactylus spectabilis. Numbers of males (open bars) and females (black bars) at the Deep 2 study site during the reproductive (May) and non-reproductive (August) seasons. Standard errors ( $n=3$ censuses) are only for dawn, midday and dusk periods

territories during further censuses of the Deep 2 study site in 1986, 1987 and 1988. The majority of interactions occurred at reeflets with definite caves and tunnels, with encounters being centred at the entrances Interactions consisted of either blocking or biting Blocking involved the parallel swimming of resident and intruder, with the resident rolling down upon the latter, thereby directing it into the substratum. Most interactions occurred during dusk, when the males were most active (Table 1). No foraging was observed by the large males over the whole of the observation period.

Females rested on the top of reeflets. Around dusk, males actively prevented the movement of females

Table 1. Cheilodactylus spectabilis. Mean percentage occurrence ( \pm SE) of actively swimming fish observed at the Deep 2 study site at 3 times of day during the breeding season $(n=3)$

Only 'swimming' and 'resting' behaviours were observed

\begin{tabular}{|lccc|}
\hline & Dawn & Midday & Dusk \\
\cline { 2 - 4 } Males & $20.3 \pm 4.2$ & $22.7 \pm 8.6$ & $56.7 \pm 16.8$ \\
Females & Not present & $34.0 \pm 9.7$ & $16.0 \pm 8.2$ \\
\hline
\end{tabular}

from their territory by swimming tight circles around them, or resting beside them. Movement of a female away from the territory resulted in pursuit by the male and blocking, or a rapid chase and biting at the base of the female's caudal fin.

The reeflets with conspicuous caves had the highest number of visits by ripe females. The reeflets where 7 or more females were observed were the only ones defended throughout the 8 mo observation period. Evidence suggests that the presence of caves is important to the spawning event. The only spawning event witnessed occurred within a shallow cave, with the male vibrating its abdomen over the distended abdomen of a prostate female.

\section{DISCUSSION}

Cheilodactylus spectabilis appears to exhibit resource defense polygyny (Krebs \& Davies 1981), with the majority of spawnings (assumed from visitations) occurring at specific sites defended by a minority of males. This bias, for both spawning sites and males, has been interpreted to be due to female choice (Searcy 1979, Downhower \& Brown 1980). Thus, female choice during the breeding season may be a major factor determining the general distribution pattern of females and juveniles inshore, and males of progressively larger size offshore (McCormick 1989). Female choice, and concomitantly male spawning success, may be attributable to either quality of the site or quality of the individual male (Warner 1987). However, females choosing high quality sites are also likely to be mating with high quality males since larger, more aggressive males are often associated with high-quality resources through male-male competition (Searcy 1979). These possibilities are inseparable without removal experiments. The few studies that have experimentally analyzed female mate choice have identified both factors as being important. Jones (1981) removed the most successful male Notolabrus celidotus from spawning territories and determined that females were choosing the spawning site rather than the resident male. In contrast, Downhower \& Brown (1980) experimentally manipulated breeding-site quality in Cottus bairdi and found no alteration in female preference for larger males. Female choice appeared to be related to the increased hatching success of nests guarded by large males.

In the present study there was a relationship between the presence of territorial males on specific reefs throughout the year, the number of visitations to these reefs by females during the breeding season, and the presence of conspicuous caves on these reeflets. Behavioural observations suggest caves are important to the spawning event and that gamete release may 
occur there. Around dusk the deep reef system is an area of high activity with suites of both diurnal and nocturnal fish being active, male Cheilodactylus spectabilis chasing females into territories, and other males defending established territories from males without territories. It may be that caves, being somewhat disjoint from this high activity, provide an area where the precision required by $C$. spectabilis for gamete release can be attained without interruption. Hixon (1981) found that certain large males of the surfperch Embiotoca jacksoni defend reef caves as mating sites off the Californian coast. Experimental occlusion of a cave prevented mating behaviour, and resulted in either abandonment or a shift in the occupant's territory. Controlled manipulations similar to this are required to test the importance of caves to the reproduction of $C$. spectabilis.

It is unknown how many spawnings are sequestered by the large males inshore compared to those in deep water. Three points are in favour of the pattern of reproduction described in this study being a general trend. Firstly, no reproductive behaviour was recorded outside the Deep 2 study site. Secondly, there is a general trend for large male Cheilodactylus spectabilis to occur predominantly in deeper water while females and juveniles occur in the shallows (McCormick 1989). Lastly, most studies that have examined male success in detail have found a strong relationship between male size, dominance and number of copulations (Robertson 1972, Perrone 1978, Thresher 1979, Schmale 1980, Jones 1981, Hoffman 1985).
Examination of the gonad maturation cycle of Cheilodactylus spectabilis supports the suggestion of it being a benthic spawning fish, with males being able to exert considerable precision in the spawning event. Males were found to have extremely small gonads when ripe and there was a large difference between the weights of the testes and ovaries for similar sized individuals. This is epitomized by a $305 \mathrm{~mm}$ SL female having a gonad mass 107 times larger than a similar sized ripe male. A comparison of the mean gonad index values for a range of teleosts places this large difference into perspective (Table 2). Values for females span 1 order of magnitude, while values for males over the 12 species of fish vary over 2 orders of magnitude.

In general, gonad size appears to be a function of the environment inhabited (reefal or open-water), reproductive behaviour and mode of spawning. For example, the schooling blue moki Latridopsis ciliaris forms aggregations which spawn over a 2 mo period in the open water off the east coast of New Zealand (Francis 1981). For a high probability of egg fertilization in this broadcast spawner, large amounts of sperm are required. Both males and females are found to have a large gonad mass. In contrast, the tripterygiid Forsterygion varium is a nest building serial spawner with the male fertilizing and guarding the egg mat laid in his territory by the female (Thompson 1979, 1986). There is a high degree of precision in the spawning event and only a small quantity of sperm is required for fertilization. Testes of this species relative to the body size are small. In a similar way, male Cheilodactylus spectabilis

Table 2. Comparison of maximum gonadosomatic index values for a range of fish species. Relative size of male and female gonads is expressed as a percentage ratio of index values. Spawning behaviour is summarized as high in the water column (pelagic) or benthic, and as a paired or group event. Cited source refers to gonadosomatic index values

\begin{tabular}{|c|c|c|c|c|c|c|}
\hline \multirow[t]{2}{*}{ Species } & \multirow[t]{2}{*}{ Family } & \multicolumn{3}{|c|}{ Gonad indices } & \multirow[t]{2}{*}{ Spawning method } & \multirow[t]{2}{*}{ Source } \\
\hline & & Female & Male & $\begin{array}{l}\% \text { male/ } \\
\text { female }\end{array}$ & & \\
\hline Latridopsis ciliaris & Latridae & 7.3 & 12.2 & 164.0 & Pelagic, group & Francis (198.1) \\
\hline Acanthurus nigrofuscus & Acanthuridae & 5.2 & 8.2 & 158.0 & $\begin{array}{l}\text { Upward dash, pair or } \\
\text { group }\end{array}$ & Fishelson et al. (1987) \\
\hline Ethmolosa fimbriata & Alosinae & 3.8 & 4.1 & 108.0 & Pelagic & Blay \& Eyeson (1982) \\
\hline Chrysophrys auratus & Sparidae & 6.9 & 6.1 & 88.0 & Pelagic, group & Crossland $(1977)$ \\
\hline Menidia menidia & Atherinidae & 14.0 & 12.0 & 85.7 & Shallows, group & Middaugh et al. (1984) \\
\hline Trachurus trachurus & Scombridae & 12.0 & 10.0 & 83.3 & Pelagic & Macer $(1974)$ \\
\hline Cheilodactylus macropterus & Cheilodactylidae & 4.3 & 3.0 & 70.6 & Pelagic & Tong \& Vooren (1972) \\
\hline Acanthopagus spp. & Sparidae & 24.0 & 4.5 & 22.5 & Pelagic, group (?) & Abu-Hakima (1984) \\
\hline Parupeneus baraberinus & Mullidae & 4.8 & 0.88 & 18.3 & $\begin{array}{l}\text { Upward dash, pair or } \\
\text { group }\end{array}$ & $\begin{array}{l}\text { Wahbeth \& Ajiad } \\
\text { (1985) }\end{array}$ \\
\hline Tripterygion varium & Tripterygiidae & 4.3 & 0.45 & 9.5 & $\begin{array}{l}\text { Benthic, nest-build- } \\
\text { ing, pair spawning }\end{array}$ & Thompson (1979) \\
\hline Trichogaster pectoralis & Anabantidae & 8.0 & 0.26 & 3.3 & $\begin{array}{l}\text { Benthic, nest-build- } \\
\text { ing, pair, parental care }\end{array}$ & $\begin{array}{l}\text { Hails \& Abdullah } \\
\text { (1982) }\end{array}$ \\
\hline Cheilodactylus spectabilis & Cheilodactyludae & 5.8 & 0.12 & 2.1 & $\begin{array}{l}\text { Benthic, pair } \\
\text { spawning }\end{array}$ & This study \\
\hline
\end{tabular}


have not only small testes but also asynchronous gonad maturation with the result that only a minute amount of sperm can be produced at any one time. This points to a reproductive mode which is both energy-conserving and efficient and which must be highly ritualized to be successful i.e. result in fertilized eggs. The link between gonad size and reproductive ecology also suggests that $C$. spectabilis will have closer affinities in reproductive behaviour to pair-spawning fish which build nests than to pelagic group-spawners. Further work is required to investigate these predictions.

In conclusion, the reefal life history of Cheilodactylus spectabilis involves a sequence of systematic movements progressively offshore. Fish recruit episodically into the intertidal shallows and gradually move into deeper water with increasing size. At the approximate size of sexual maturity females recruit into loose conspecific foraging groups at mid-depths, while juvenile males form similar groups in deeper water (McCormick 1986, 1989). The most dominant large males then establish territories on the reef edge which are visited during the breeding season by ripe females. This study suggests that this movement pattern is driven by competition between males for spawning sites which are chosen by females. However, removal experiments are required to determine whether mate or spawning site selection is the prime influential factor. Further work is also required to determine the generality of deep water spawning sites.

Acknowledgements. This study is a contribution from the Leigh Marine Laboratory of the University of Auckland. I am grateful for the financial and logistic support of this facility. Many thanks to Howard Choat and Brigid Kerrigan who discussed the work with me and commented on the manuscript.

\section{LITERATURE CITED}

Abu-Makima, R. (1984). Some aspects of the reproductive biology of Acanthopagrus spp. (Family: Sparidae). J. Fish. Biol. 25: 515-526

Blay, J., Eyeson, K. N. (1982). Observations on the reproductive biology of the shad, Ethmalosa fimbriata (Bowdich), in the coastal waters of Cape Coast, Ghana. J. Fish. Biol. 21: 485-496

Choat, J. H., Robertson, (1975). Protogynous hermaphroditism of the family Scaridae. In: Reinboth, R. (ed.) Intersexuality in the animal kingdom. Springer-Verlag, Berlin, p. $263-283$

Crossland, J. (1977). Seasonal reproductive cycle of snapper, Chrysophrys auratus (Forster), in the Hauraki Gulf. N. Z. Jl mar. Freshwat. Res. 11. 37-60

Downhower, J. F., Brown, L. (1980). Mate preference of female mottled sculpins, Cottus bairdi. Anim. Behav. 28: $728-734$

Fischer, E. A. (1980). The relationship between mating systems and simultaneous hermaphroditism in the coral reef fish, Hypoplectrus nigricans (Serranidae). Anim. Behav. 28: 620-633
Fishelson, L., Montgomery, L. W.. Myrberg, A. H. (1987). Biology of surgeonfish Acanthurus nigrofuscus with emphasis on changeover in diet and annual gonadal Cycles. Mar Ecol. Prog. Ser. 39: 37-47

Francis, M. P. (1981). Age and growth of moki, Latridopsis ciliaris (Teleostei: Latridae). N. Z. Jl mar Freshwat. Res. 15: $47-49$

Hails, A. J., Abdullah, Z. (1982). Reproductive biology of the tropical fish Trichogaster pectoralis (Regan). J. Fish. Biol. 21: $157-170$

Hixon, M. A. (1981). An experimental analysis of territoriality in the Californian reef fish Embiotica jacksoni (Embiotocidae). Copeia 1981: 653-665

Hoffman, S. G. (1985). Effects of size and sex on the social organization of reef-associated hogfishes, Bodianus spp. Environ. Biol. Fish. 14: 185-197

Johannes, R. E. (1978). Reproductive strategies of coastal marine fishes in the tropics. Environ. Biol. Fish. 3: 65-84

Johannes, R. E. (1981). Words of the lagoon. Univ. Calif. Press, Los Angeles

Jones, G. P. (1981). Spawning-site choice by female Pseudolabrus celidotus (Pisces: Labridae) and its influence on the mating system. Behav. Ecol. Sociobiol. 8: 129-142

Jones, G. P. (1984). Population ecology of the temperate reef fish Pseudolabrus celidotus Bloch \& Schneider (Pisces: Labridae). II. Factors influencing adult density. J. exp. mar Biol. Ecol. 75: 277-303

Krebs, J. R, Davies, N. B. (1981). An introduction to behavioural ecology. Blackwell Scientific Publications, Oxford

Macer, C. T. (1974). The reproductive biology of the horse mackerel Trachurus trachurus (L.) in the North Sea and English Channel. J. Fish. Biol. 6: 415-438

McCormick, M. I. (1986). Spatial and temporal patterns of abundance of Cheilodactylus spectabilis (Pisces: Cheilodactylidae). M. Sc. thesis, University of Auckland

McCormick, M. I. (1989). Spatio-temporal patterns in the abundance and population structure of a large temperate reef fish. Mar Ecol. Prog. Ser 53: 215-225

McCormick, M. I., Choat, J. H. (1987). Estimating total abundance of a large temperate-reef fish using visual striptransects. Mar Biol. 96: 467-478

Middaugh, D. P., Domey, R. G., Scott, G. I. (1984), Reproductive rhythmicity of the Atlantic Silverside. Trans. Am. Fish Soc. 113: $472-478$

Moe, M. A. (1969). Biology of the red grouper Epinephelus morio (Valencinnes) from the eastern Gulf of Mexico. Florida Dept. Natural Resources Laboratory. Professional paper series, 10

Perrone, M. (1978). Mate size and breeding success in a monogamous cichlid fish. Environ. Biol. Fish. 3: 193-201

Randall, J. E., Randall, H. A. (1963). The spawning and early development of the Atlantic parrotfish, Sparisoma rubripinne, with notes on other scarid and labrid fishes. Zoological 48: 49-60

Robertson, D. R. (1972). Social control of sex reversal in a coral-reef fish. Science 177: 1007-1009

Robertson, D. R. (1983). On the spawning behavior and spawning cycle of eight surgeonfishes (Acanthuridae) from the Indo-Pacific. Environ. Biol. Fish. 9: 193-223

Schmale, M. C. (1980). A preliminary report on sexual selection in the bicolor damselfish, Eupomacentrus partitus. Bull. mar. Sci. 30: 328

Searcy, W. A. (1979). Female choice of mates: a general model for birds and its application to red-winged blackbirds (Agelaius phoeniceus). Am. Nat. 114: 77-100

Thompson, S. (1979). Ecological and behavioural factors influencing the distribution and abundance patterns of 
Tripterygiid fishes with particular reference to Tripterygion varium. $\mathrm{M}$. Sc thesis, University of Auckland

Thompson, S. (1986). Male spawning success and female choice in the mottled triplefin, Forsterygion varium (Pisces: Tripterygiidae). Anim. Behav. 34: 580-589

Thresher, R. E. (1979). Social behavior and ecology of two sympatric wrasses (Labridae: Halichoeres spp.) off the coast of Florida. Mar. Biol. 53: 161-172

Thresher, R. E. (1984). Reproduction in reef fishes. TFH Publications, Neptune, New Jersey

Tong, L. J., Vooren, C. M. (1972). The biology of the New Zealand Tarakihi, Cheilodactylus macropterus (Bloch and

This article was presented by Dr A. J. Underwood, Sydney, Australia
Schneider). Fisheries Research Division, New Zealand, Ministry of Agriculture and Fisheries, Fisheries Research Bulletin 6

Wahbeth, M. I., Ajiad, A. (1985). Reproductuve biology and growth of the goatfish, Parupereus barberinus (Lacepede) in Aqaba, Jordan. J. Fish. Biol. 26: 583-590

Warner, R. R. (1987). Female choice of sites versus mates in a coral reef fish, Thalassoma bifasciatum. Anim. Behav. 35: $1470-1478$

Yamamoto, K., Yoshioka, H. (1964). Rhythm of development in the oocyte of the medaka, Oryzias latipes. Bull. Fac. Fish. Hokkaido Univ. 15: 5-19

Manuscript first received: May 11, 1988

Revised version accepted: April 18, 1989 